PRACE GEOGRAFICZNE

zeszyt 149, 2017, 101-121

doi: 10.4467/20833113PG.17.012.6928

Instytut Geografii i Gospodarki Przestrzennej UJ

Wydawnictwo Uniwersytetu Jagiellońskiego

\title{
LOKALNE ORGANIZACJE TURYSTYCZNE JAKO CZYNNIK ROZWOJU REGIONALNEGO - OCENA FUNKCJONOWANIA
}

\author{
Agata Stefanowska, Maria Lipko-Kowalska
}

\section{Local Tourism Organisations as a factor for regional development: Functional assessment}

\begin{abstract}
Tourism development is perceived as one of the strategies with a positive impact on national and local economies. Following global trends these three levels was introduced in Poland in 2000 for organisations devoted to the development and promotion of tourism. This paper focuses on tourism development at the local level, i.e. Local Tourism Organisations (LTOs). It aims to assess whether the 3-tier tourism development system complies with its purpose at the LTO level. In 2013, questionnaires were sent to all LTOs registered in Poland (only 30 of 130 LTOs participated in the research), and next to members of these LTOs, which completed the survey ( 88 of 500 participated in the research). Study results suggest that LTOs do fulfil their primary task of contributing to the development of tourism in the region. The main advantages of membership are marketing benefits and the consolidation of activities with other members. Moreover, the presence of LTOs on the local market supports activities associated with tourism promotion. Despite the positive study results, the functioning of LTOs in Poland requires corrective measures. Organisations should place stronger emphasis on the integration of the various stakeholder groups in the region and become more involved in inter-regional cooperation and the development of new tourism products.
\end{abstract}

Keywords: regional development, local tourist organisations, LTO, intersectoral collaboration, promotion 
Zarys treści: Rozwój turystyki jest czynnikiem przynoszącym pozytywny wpływ na narodową i lokalną gospodarkę. W Polsce w roku 2000 wprowadzono hierarchiczną strukturę organizacji zajmujących się rozwojem i promocją turystyki. Niniejsze opracowanie dotyczy rozwoju turystyki na poziomie lokalnym z punktu widzenia działalności Lokalnych Organizacji Turystycznych (LOT). Celem niniejszego artykułu jest zbadanie, czy trójstopniowy system rozwoju turystyki POT-ROT-LOT spełnia swoje zadanie na poziomie lokalnym. W 2013 r. przeprowadzono, drogą elektroniczną, badania ankietowe wśród wszystkich zarejestrowanych LOT-ów, czyli 130, spośród których ankiety wypełniło jedynie 30. W badaniach wzięli udział także członkowie LOT-ów, którzy wypełnili i odesłali kwestionariusze, czyli 88 podmiotów. Na podstawie wyników badań można stwierdzić, że LOT-y spełniają swoje podstawowe zadanie - przyczyniają się do rozwoju turystyki w regionach. Główne korzyści, czerpane z przynależności do organizacji, to korzyści marketingowe i możliwość konsolidacji działań z innymi członkami. Obecność LOT-ów na lokalnym rynku wspiera również działania związane z promocją turystyki. Mimo pozytywnych wyników badań funkcjonowanie LOT-ów w Polsce ma też wady, które wymagają działań naprawczych. Organizacje powinny zwrócić większą uwagę na integrację różnych grup interesu występujących na danym obszarze, a także bardziej zaangażować się we współpracę międzyregionalną i tworzenie nowych produktów turystycznych.

Stowa kluczowe: rozwój regionalny, lokalne organizacje turystyczne (LOT), współpraca międzysektorowa, promocja

\section{Wstęp}

W Polsce w roku 2000 wprowadzono hierarchiczną strukturę organizacji zajmujących się rozwojem i promocją turystyki. Główną, narodową organizacją zajmującą się promowaniem kraju jako atrakcyjnego turystycznie jest Polska Organizacja Turystyczna (POT). Niżej w hierarchii znajdują się Regionalne Organizacje Turystyczne (ROT) oraz Lokalne Organizacje Turystyczne (LOT), które mają na celu promocję turystyczną obszaru ich działania, wspomaganie funkcjonowania i rozwoju informacji turystycznej, inicjowanie, opiniowanie i wspieranie planów rozwoju i modernizacji infrastruktury turystycznej oraz współpracę z Polską Organizacją Turystyczną ${ }^{1}$. Zadania LOT dotyczą głównie opracowania wspólnego sytemu promocji, opartego na współpracy jednostek samorządu lokalnego (gminy, powiaty) i branży turystycznej oraz innych zainteresowanych rozwojem turystyki podmiotów. Ponadto zajmują się tworzeniem, rozwojem i promocją nowych produktów turystycznych. Istotnymi zadaniami LOT-ów jest także gromadzenie i aktualizacja informacji o atrakcjach i produktach turystycznych oraz utrzymanie i prowadzenie lokalnych punktów informacji turystycznej. Zasięg działania LOT-ów odpowiada swoją wielkością obszarowi

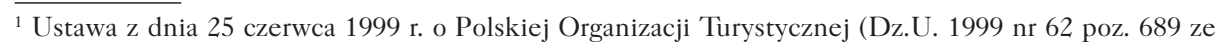
zm.; t.j. Dz.U. 2016 poz. 156). 
skupionych w nich jednostek samorządu lokalnego (najczęściej jednego lub kilku powiatów lub kilku gmin, na których terenie zlokalizowane są atrakcje turystyczne).

Po 16 latach (2000-2016) działania hierarchicznego systemu w Polsce w niniejszym artykule dokonano analizy funkcjonowania LOT-ów i ich członków. Sformułowano następujące pytania badawcze:

1) W jaki sposób LOT-y stymulują rozwój lokalny na obszarze swojego działania w opinii ich członków?

2) Jakie korzyści czerpią członkowie LOT-ów z przystąpienia do organizacji?

3) Czy obecność LOT-ów na lokalnym rynku pomaga oraz wspiera działania związane z szeroko pojętym rozwojem oraz promocją turystyki?

\section{Strategie rozwoju lokalnego i regionalnego}

Rozwój lokalny związany jest przede wszystkim z określonym miejscem działania. Na dynamikę i skalę procesów rozwojowych, które zachodzą w określonej jednostce terytorialnej, wpływa m.in. jej położenie geograficzne (Dynowska, Rudowicz 2007). Reforma ustroju terytorialno-administracyjnego, która została przeprowadzona w Polsce w 1999 r., zapoczątkowała proces istotnych zmian w systemie zarządzania rozwojem lokalnym i regionalnym. W wielu krajach w procesie zmian w tym systemie zarządzania (Cruz, Marques 2014) istotną rolę odegrało państwo, a także jednostki samorządu terytorialnego (Szewczuk i in. 2011). Cuadrado-Ballesteros (2014) uważa, że istotnym celem działalności jednostek samorządowych jest tworzenie właściwych warunków do rozwoju wspólnoty.

Istotnym etapem efektywnego zarządzania rozwojem lokalnym i regionalnym jest identyfikacja szans i zagrożeń dla obszaru. Ważne jest także całościowe oddziaływanie władz samorządowych na społeczność lokalną, gospodarkę czy przestrzeń. Nermend (2009), jako czynniki warunkujące rozwój regionalny, wskazuje: mieszkańców, środowisko przyrodnicze, zaplecze techniczne regionu, zasoby ekonomiczne oraz wyjściowy poziom rozwoju. Stimson i in. (2006) podkreślają, że w procesie rozwoju regionalnego istotny jest nie tylko stan systemu ekonomicznego obszaru, ale także zasoby społeczne i kulturowe, wiedza, umiejętność zarządzania ryzykiem oraz stale ulepszany system rządzenia. Nowacki (2009: 63) stwierdza, że część składowych rozwoju regionalnego „ma charakter wewnętrzny (endogeniczny), część zewnętrzny (egzogeniczny), część natomiast określa zdolność regionu do reagowania na zmiany w jego makrootoczeniu". Wśród licznych czynników, które determinują rozwój regionalny, bardzo ważną rolę odgrywa polityka innowacji (w zakresie nauki i technologii), warunkująca wzrost gospodarczy (Howells 2005) i stanowiąca często kluczowy czynnik w kreowaniu dobrobytu i zrównoważonego rozwoju w regionach (Sleuwaegen, Boiardi 2014). Różne rodzaje innowacji w turystyce są często osiągane w ścisłej współpracy z innymi podmiotami - z sektora publicznego, prywatnego 
i non-profit. Taka kooperacja jest związana ze złożonym charakterem regionalnego produktu turystycznego, który jest kreowany przez wiele różnych podmiotów (dysponujących wiedzą, doświadczeniem, kapitałem itp.), niezbędnym do powstania innowacji (Czernek 2015). Partnerstwo turystyczne w regionie wymaga uświadomienia sobie wysokiego stopnia współzależności, określenia indywidualnych i wspólnych korzyści płynących ze współpracy, poczucia pewności co do realizacji wspólnych decyzji i działań, zaangażowania kluczowych dla rozwoju turystyki w regionie podmiotów oraz przyjęcia strategii zawierającej jasno określoną wizję rozwoju (Zmyślony 2008).

\section{Turystyka jako czynnik rozwoju lokalnego i regionalnego}

Na świecie rozwój turystyki postrzegany jest jako jedna ze strategii mających pozytywny wpływ na narodową i lokalną gospodarkę (Sharpley 2002; McLennan i in. 2014). Turystyka często wskazywana jest jako skuteczny katalizator procesu odbudowy i rozwoju państwa, jej wkład w ogólny rozwój społeczno-gospodarczy obszaru zależy jednak od wielu czynników. Są to m.in.: charakter środowiska, polityka lokalnych władz oraz decyzje podejmowane przez menedżerów branży turystycznej (Telfer 2005).

W ostatnich latach znaczenia nabrał lokalny, samokreujący się i samokontrolujący się wymiar turystyki, polegający na zaangażowaniu lokalnych podmiotów: władz samorządowych, przedsiębiorców i stowarzyszeń turystycznych (Giannone 2002). Według Capone i Boix (2008) plany rozwoju turystyki na poziomie lokalnym ściśle zależą nie tylko od sytuacji lokalnej, ale także od sytuacji ekonomicznej regionu i całego kraju, zatem zarówno lokalne, jak i regionalne czynniki determinują potencjalny sukces rozwoju turystyki danego obszaru (Yang, Fik 2014). Warunkiem skutecznej transformacji regionów poprzez turystykę powinna być efektywna polityka turystyczna oraz wsparcie regionu przez edukację i szkolenia branżowe (Russell, Faulkner 2004). Według Telfera (2005) rzeczywiste korzyści płynące z turystyki dla danego obszaru zależą w dużej mierze od tego, jakie formy i rozmiary turystyki uzna się za dopuszczalne i kto będzie sprawował nad nią kontrolę.

Budując wspólną turystykę regionu, należy zwrócić szczególną uwagę na współpracę różnych interesariuszy. Dzięki kooperacji, możliwe jest m.in. uniknięcie kosztów związanych z rozwiązywaniem problemów między zainteresowanymi stronami (Healey 1998) czy przeprowadzenie kompleksowej analizy wpływu turystyki na środowisko ekonomiczne, społeczne i przyrodnicze (Bramwell, Sharman 1999). Taka kooperacja możliwa jest często dzięki tworzeniu tzw. klastrów. Kluczową funkcją tych organizacji jest wejście na lokalny rynek, co powoduje współpracę dla większych korzyści, niż byłoby to możliwe przy indywidualnych budżetach marketingowych. Jak twierdzi Jackson i Murphy (2006), organizacje tego typu powinny spojrzeć 
poza krótkoterminowe plany biznesowe i skupić swoje działania na inwestowaniu w rozwój obszaru.

\section{Rozwój turystyki w Polsce i innych krajach Europejskich}

W celu rozwoju turystyki w wielu krajach na świecie wprowadzono trójstopniowy system promocji kraju, w którym LOT-y powinny odgrywać strategiczną rolę w rozwoju regionów. W niektórych krajach europejskich hierarchiczny system promocji turystyki istnieje od wielu lat, np. w Szwecji powstał on już w 1976 r. (Pearce 1996), a w Szkocji w 1982 r. (Kerr i in. 2001), warto jednak porównać sytuację Polski z sytuacją innych krajów europejskich, zbliżonych pod względem położenia (Europa Środkowa) oraz historii (np. Słowacja, Republika Czeska, Węgry i Bułgaria). Po czterdziestoletnim okresie komunizmu, na początku lat 90., wszystkie te kraje doświadczyły dużych zmian strukturalnych, gospodarczych i społecznych. Nastąpił również rozwój turystyki związany m.in. z otwarciem granic tych krajów. Śladem krajów zachodnich omawiane państwa utworzyły zarówno administrację krajową, odpowiedzialną za turystykę, jak i narodowe organizacje turystyczne. Organizacje większości wymienionych krajów powstały jednak wcześniej niż POT (utworzony w 2000 r.). Pierwszą z nich utworzono w Czechach w 1993 r. (Czech Tourist Authority, CTA), rok później powstały organizacje na Słowacji (Slovak Tourist Board, STB) oraz na Węgrzech (Hungarian National Tourist Office, HNTO). Wszystkie mają zbliżone cele oraz obowiązki i zadania do POT. Jednym z istotnych zadań, podobnie jak w Polsce, jest stymulowanie tworzenia regionalnych i lokalnych organizacji turystycznych w danym kraju, mających na celu promocję obszarów oraz tworzenie produktów turystycznych (Adamczyk 2005). W Bułgarii z kolei reforma systemu turystyki nastąpiła, tak jak w Polsce, po 2000 r., kiedy został utworzony trójstopniowy system organizacji promujących turystykę, nadzorowany przez Ministerstwo Ekonomii i Energii ('Tapescu 2015).

W Słowacji jednym z zadań organizacji tworzonych na poziomie lokalnym i regionalnym jest tworzenie możliwości współpracy i zaangażowania publicznych i prywatnych jednostek, w tym przedsiębiorstw, zainteresowanych rozwojem turystyki, których zadaniem byłoby również wsparcie finansowe. Pavlíková (2014) zwraca jednak uwagę, że rzeczywisty rozwój na poziomie regionalnym nastąpił w Słowacji dopiero po 2001 r., jako konsekwencja reformy administracji publicznej i przeprowadzenia decentralizacji władzy. Malachovský i Királová (2015) dowodzą, że zarówno na Słowacji, jak i w Czeskiej Republice nie ma efektywnego systemu zarządzania turystyką na poziomie narodowym, regionalnym i lokalnym w zakresie turystyki krajowej i zagranicznej. 


\section{Metodyka}

W celu odpowiedzi na pytania badawcze, między marcem a listopadem 2013 r., zostały przeprowadzone dwustopniowe badania ankietowe. W pierwszym etapie wysłano drogą elektroniczną kwestionariusze ankiety do wszystkich LOT-ów zarejestrowanych w Polsce (130 organizacji, na podstawie danych POT- http://pot.gov.pl/, 29.09.2016) z prośbą o odesłanie wypełnionego dokumentu przez pracowników LOT-ów. W drugiej kolejności badaniami objęto członków tych LOT-ów, które odpowiedziały na ankietę. Dzięki temu możliwe było skonfrontowanie opinii obu grup badanych (LOT-ów i ich członków) w zakresie rozwoju turystyki na poziomie lokalnym.

W obu przypadkach kwestionariusze zostały udostępnione za pomocą internetowego systemu rozsyłania ankiet (www.ankietka.pl). Niestety ta forma zbierania danych okazała się mało efektywna, mimo że do podmiotów, które nie odesłały ankiety, przypomnienie z prośbą o wypełnienie wysyłano trzykrotnie. W pierwszym etapie badań ankietę wysłano do 130 LOT-ów. Wypełnione ankiety otrzymano od 30 organizacji (23\%). W ponad 30 przypadkach adresy mailowe, podane na oficjalnych stronach internetowych, okazały się nieaktywne, co już negatywnie wpływa na wizerunek organizacji mających za cel główny promocję turystyki w regionie.

W drugiej części badań ankiety rozesłano do członków tych 30 organizacji, które wzięły udział w pierwszym etapie badań. Bazę członków stworzono na podstawie danych ze stron internetowych LOT-ów; w sumie wysłano ankietę do 500 adresatów, z czego w badaniu wzięło udział tylko 88 podmiotów (18\%). Podsumowując, do analizy statystycznej wzięto pod uwagę: 30 Lokalnych Organizacji Turystycznych oraz 88 członków tych organizacji. Ze względu na tak niewielką skuteczność zbierania danych próby nie można uznać za reprezentatywną, jedynie za próbę dostępnościową. Kwestionariusze ankiety zostały opracowane na potrzeby niniejszego badania.

Podstawowe zagadnienia, jakie poruszono w badaniu to: motywy przystąpienia do organizacji, korzyści z członkostwa w organizacji, problemy w funkcjonowaniu LOT-ów, opinie dotyczące niezbędnych działań na rzecz poprawy działalności LOT, wpływ działalności LOT-ów na rozwój turystyki w regionie, umiejętność współpracy ponadlokalnej.

Analizę zebranych danych przeprowadzono za pomocą programu Statistica 10, zastosowano różne testy statystyczne w zależności od charakteru zmiennych. W przypadku zmiennych jakościowych posłużono się funkcją chi-kwadrat w postaci logarytmicznej. Do analizy zmiennych porządkowych posłużono się testem U Manna-Whitneya dla dwóch grup niezależnych. 


\section{Wyniki badań}

W pierwszej części badań wzięło udział 30 LOT-ów. Scharakteryzowano je pod względem lokalizacji, wielkości (liczby członków) i czasu funkcjonowania. Wśród organizacji biorących udział w badaniu dominowały te najmniejsze - zrzeszające poniżej 25 członków, oraz organizacje z kilku- lub kilkunastoletnim doświadczeniem - powstałe przed 2005 r. (tab. 1).

Biorąc pod uwagę lokalizację LOT-ów, dominowały organizacje z północy Polski, z województw: warmińsko-mazurskiego, zachodniopomorskiego i pomorskiego (w sumie 48\%), a najmniej z części środkowej Polski. Mimo małej liczby uczestników badania każde województwo, z wyjątkiem łódzkiego i świętokrzyskiego, miało swojego reprezentanta (ryc. 1). Ze względu na niewielki procent organizacji, które zgodziły się na udział w badaniu, nie było możliwe przeprowadzeni bardziej szczegółowej analizy pod kątem zróżnicowania przestrzennego wyników.

Druga część badań dotyczyła członków LOT-ów, których scharakteryzowano pod względem: członkostwa w określonej organizacji, roku przystąpienia do LOT-u i sektora (obszaru) działalności. Najwięcej członków zadeklarowało przystąpienie do organizacji w latach 2004-2013, z czego 13,64\% badanych wstąpiło do LOT-u w 2011 r. Zapisywanie się członków (takich jak samorządy, przedsiębiorcy czy osoby prywatne) nie zawsze następowało w roku ich założenia. Połowa organizacji biorących udział w badaniu powstała do 2005 r., ale w tym czasie wstąpiła do nich tylko 1/4 ankietowanych członków. Z kolei najliczniej członkowie wstępowali do organizacji w latach 2006-2010, kiedy powstało ok. 1/3 badanych LOT-ów.

Wśród wszystkich członków badanych LOT-ów (wg danych uzyskanych od organizacji), dominują przedsiębiorcy oraz osoby prywatne, a 1/5 stanowią władze samorządowe. Biorąc natomiast pod uwagę tylko tych członków LOT-ów, którzy

Tab. 1. Podział LOT-ów biorących udział w badaniu, w zależności od liczby członków

Table 1. LTOs participating in the survey, according to the number of members

\begin{tabular}{|c|c|c|}
\hline $\begin{array}{c}\text { Wielkość organizacji } \\
\text { (w zależności od liczby członków) } \\
\text { The size of the organization } \\
\text { (depending on the number of members) }\end{array}$ & $\begin{array}{c}\text { Liczba organizacji } \\
\text { określonej wielkości } \\
\text { Number of organizations } \\
\text { with specific size }\end{array}$ & $\begin{array}{c}\% \text { organizacji określonej wielkości } \\
\% \text { of organizations with specific size }\end{array}$ \\
\hline$<25$ & 13 & 20 \\
\hline $26-50$ & 6 & 23 \\
\hline $51-75$ & 7 & 10 \\
\hline $76-100$ & 3 & 3 \\
\hline$>100$ & 1 & 2 \\
\hline
\end{tabular}




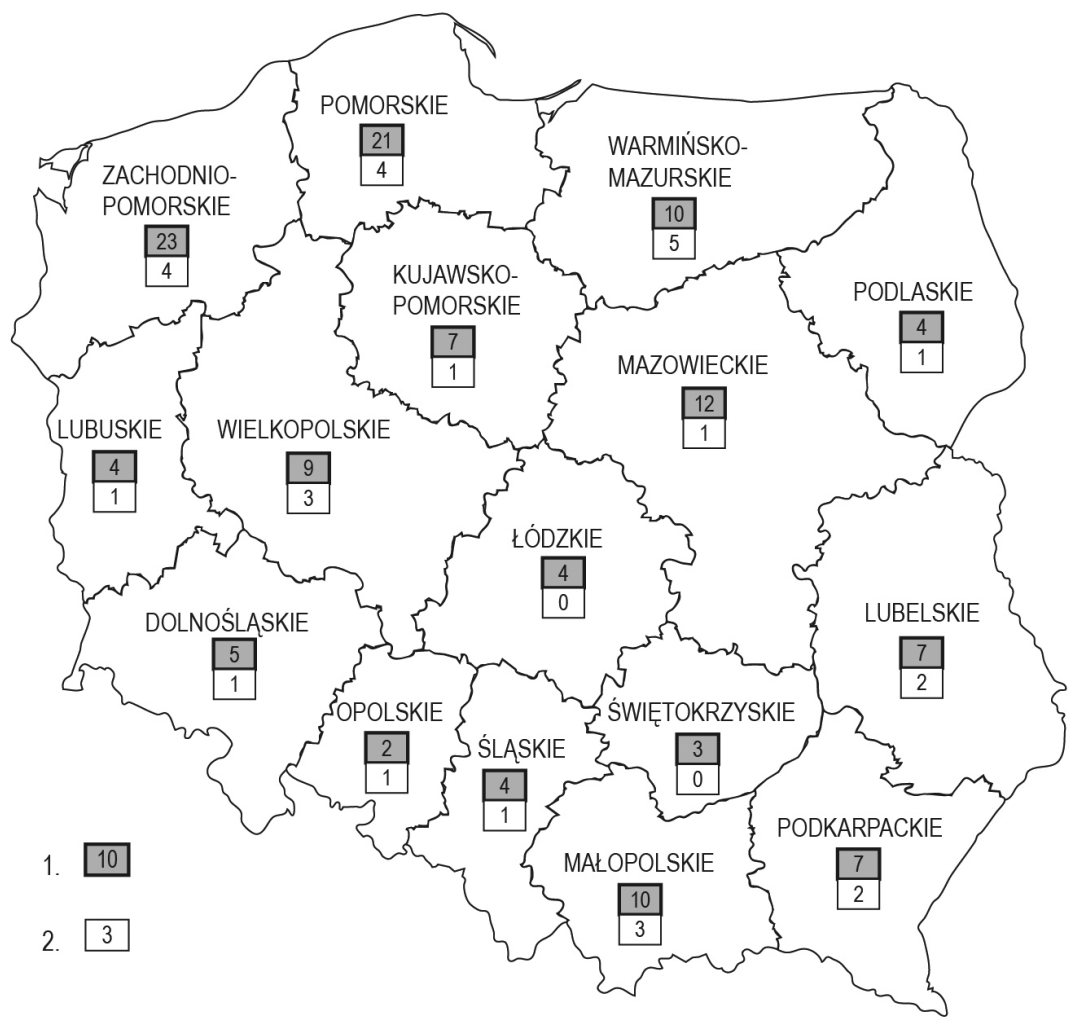

Ryc. 1. Rozkład wszystkich LOT-ów, oraz LOT-ów biorących udział w badaniu, w poszczególnych województwach

Fig. 1. Location of all LTOs, and LTOs involved in the study, in particular voivodeships

Objaśnienia: 1 - liczba wszystkich LOT w województwie; 2 - liczba LOT, które wzięły dział w badaniu. Wykaz poszczególnych LOT-ów biorących udział w badaniu: Województwo Dolnośląskie: Stowarzyszenie Gmin Turystycznych Wzgórz Trzebnickich i Doliny Baryczy; Województwo Kujawsko-Pomorskie: ankieta anonimowa; Województwo Lubelskie: LOT Roztocze, LOT Powiśle; Województwo Lubuskie: Stowarzyszenie Turystyczne Ziemi Wschowskiej; Województwo Małopolskie: Gorczańska Organizacja Turystyczna, LOT Pieniny - Kraina niezwykła, Tarnowska Organizacja Turystyczna; Województwo Mazowieckie: LOT Mazowsza Zachodniego; Województwo Opolskie: Kluczborsko-Oleska Lokalna Organizacja Turystyczna; Województwo Podkarpackie: LOT Beskid Niski, LOT Wrota Karpat Wschodnich; Województwo Podlaskie: LOT Brama na Bagna; Województwo Pomorskie: Ustka i Ziemia Słupska, Powiślańska Organizacja Turystyczna, Stowarzyszenie Turystyczne Sopot, Kaszuby Północne; Województwo Śląskie: Wiślańska Organizacja Turystyczna; Województwo Warmińsko-Mazurskie: LOT Kraina Nieodkrytych Tajemnic, Zachodnio-Mazurska LOT, LOT Ziemia Mrągowska, LOT Powiatu Szczycieńskiego, LOT Ziemi Oleckiej; Województwo Wielkopolskie: Poznańska LOT, LOT MARINA, Organizacja Turystyczna Szlak Piastowski; Województwo Zachodniopomorskie: Organizacja Turystyczna Doliny Dolnej Odry, LOT Czaplinek, LOT Dorzecza Parsęty, ankieta anonimowa 
wzięli udział w badaniu, podział wygląda inaczej - dominują władze samorządowe oraz członkowie nieujęci w podziale (odpowiedź „pozostałe” - głównie gospodarstwa agroturystyczne). Dokładne dane zawarto w tab. 2.

Jednym z głównych celów działalności LOT-ów jest rozwój turystyki w regionie poprzez różne działania. Obie grupy ankietowanych poproszono o ocenę rozwoju turystyki na obszarze ich funkcjonowania. Opinie LOT-ów i ich członków nie różniły się istotnie (test U Manna-Whitneya, $p=0,8747$ ). W przypadku większości obszarów zarówno LOT-y, jak i ich członkowie wskazali na rozwój turystyki - ponad połowa ankietowanych wskazała na nieznaczny rozwój $(57,63 \%)$, a ponad $1 / 4$ na bardzo szybki rozwój turystyki (26,27\%). Równocześnie nieliczni ankietowani zaobserwowali

Tab. 2. Porównanie struktury LOT-ów i członków LOT-ów biorących udział w badaniu Table 2. Comparison of the structure of LTOs and LTO members participating in the study

\begin{tabular}{|l|c|c|}
\hline \multicolumn{1}{|c|}{$\begin{array}{c}\text { Sektor działalności } \\
\text { Sector }\end{array}$} & $\begin{array}{c}\text { Członkowie LOT bioracy udział } \\
\text { w badaniu [\%] } \\
\text { LTOs members participating in the study }\end{array}$ & $\begin{array}{c}\text { Wszyscy członkowie LOT } \\
\text { (wg danych organizacji) [\%] } \\
\text { All members of LTO (according } \\
\text { to data from the organization) [\%] }\end{array}$ \\
\hline $\begin{array}{l}\text { Władze samorzadowe } \\
\text { Self-governments }\end{array}$ & 40,9 & 20,9 \\
\hline $\begin{array}{l}\text { Przedsiębiorstwa } \\
\text { Enterprises }\end{array}$ & 18,2 & 36,6 \\
\hline $\begin{array}{l}\text { Kluby i stowarzyszenia } \\
\text { Clubs and associations }\end{array}$ & 5,7 & 9,9 \\
\hline $\begin{array}{l}\text { Osoby prywatne } \\
\text { Private individuals }\end{array}$ & 13,6 & 27,4 \\
\hline $\begin{array}{l}\text { Pozostałe } \\
\text { Other }\end{array}$ & 21,6 & 5,2 \\
\hline
\end{tabular}

Explanations: 1 - the total number of LTOs in the voivodship; 2 - number of LTOs, that took part in the research. The list of individual organizations participating in the survey: Dolnośląskie Voivodship: Stod warzyszenie Gmin Turystycznych Wzgórz Trzebnickich i Doliny Baryczy; Kujawsko-Pomorskie Voivodship: anonymous questionnaire; Lubelskie Voivodship: LTO Roztocze, LTO Powiśle, Stowarzyszenie Turystyczne Ziemi Wschowskiej; Małopolskie Voivodship: Gorczańska Organizacja Turystyczna, LTO Pieniny - Kraina niezwykła, Tarnowska Organizacja Turystyczna; Mazowieckie Voivodship: LTO Mazowsza Zachodniego; Opolskie Voivodship: Kluczborsko-Oleska LTO; Podkarpackie Voivodship: LTO Beskid Niski, LTO Wrota Karpat Wschodnich; Podlaskie Voivodship: LTO Brama na Bagna; Pomorskie Voivodship: Ustka i Ziemia Słupska, Powiślańska Organizacja Turystyczna, Stowarzyszenie Turystyczne Sopot, Kaszuby Północne; Śląskie Voivodship: Wiślańska Organizacja Turystyczna; Warmińsko-Mazurskie Voivodship: LTO Kraina Nieodkrytych Tajemnic, Zachodnio-Mazurska LTO, LTO Ziemia Mrągowska, LTO Powiatu Szczycieńskiego, LTO Ziemi Oleckiej; Wielkopolskie Voivodship: Poznańska LTO, LTO Marina, Organizacja Turystyczna Szlak Piastowski; Zachodniopomorskie Voivodship: Organizacja Turystyczna Doliny Dolnej Odry, LTO Czaplinek, LT Dorzecza Parsęty, anonymous questionnaire 
regres w tej dziedzinie (6,77\%). Czynnikiem wpływającym na rozwój turystyki w regionie mogą być atrakcje turystyczne oraz walory przyrodnicze znajdujące się na terenach działalności LOT-ów. Opinie LOT-ów, a także ich członków, są zbliżone w tej kwestii. Ponad 1/5 z nich (26\%) ocenia atrakcje turystyczne bardzo dobrze, a $47 \%$ - dobrze. Równocześnie tylko $4 \%$ badanych oceniło je źle lub bardzo źle. Atrakcje te zwiększają liczbę turystów na terenie działalności LOT-u. Ankietowani podobnie ocenili walory przyrodnicze. Ponad 90\% LOT-ów i ich członków deklarowało, że walory te są ważnym lub bardzo ważnym aspektem, który może potęgować ruch turystyczny na terenie ich działalności. Istotnym zagadnieniem jest jednak, w jakim stopniu to działalność LOT-ów przyczynia się do rozwoju turystyki w regionie (tab. 3). Ponad połowa ankietowanych uważa, że LOT-y częściowo wpływają na rozwój turystyki, a dla 1/4 LOT-y mają bardzo duże znaczenie dla rozwoju turystyki. Niecałe $10 \%$ ankietowanych nie dostrzega pozytywnego wpływu LOT-ów.

Lokalne organizacje turystyczne działają dzięki swoim członkom. Interesujące są motywy, które skłoniły różne przedsiębiorstwa, samorządy czy osoby prywatne do przystąpienia do LOT-ów. Respondenci, w odpowiedziach własnych, zadeklarowali, że głównym argumentem chęci członkostwa w organizacji była możliwość rozrekla-

Tab. 3. Wpływ działalności LOT-ów na rozwój turystyki w regionie, w opinii członków Table 3. Impact of LTO activity on tourism development in the region: members' opinions

\begin{tabular}{|c|c|c|}
\hline $\begin{array}{l}\text { Opinie członków } \\
\text { Members' opinions }\end{array}$ & $\begin{array}{l}\text { Liczba członków wyrażających } \\
\text { daną opinię } \\
\text { Number of members expressing } \\
\text { a particular opinion }\end{array}$ & $\begin{array}{l}\% \text { członków wyrażających } \\
\text { daną opinię } \\
\% \text { of members expressing } \\
\text { a particular opinion }\end{array}$ \\
\hline $\begin{array}{l}\text { LOT ma bardzo duże znaczenie w rozwoju } \\
\text { turystyki } \\
\text { LTOs are highly significant for tourism } \\
\text { development }\end{array}$ & 22 & 25,00 \\
\hline $\begin{array}{l}\text { LOT częściowo przyczynia się do rozwoju turystyki } \\
\text { LTOs partly contribute to tourism development }\end{array}$ & 48 & 54,55 \\
\hline $\begin{array}{l}\text { Nie mam zdania } \\
\text { I do not have an opinion }\end{array}$ & 10 & 11,36 \\
\hline $\begin{array}{l}\text { LOT raczej nie wpływa na rozwój turystyki } \\
\text { Tourism development is rather uninfluenced by } \\
\text { LTOs }\end{array}$ & 6 & 6,82 \\
\hline $\begin{array}{l}\text { Brak widocznego wpływu LOT na rozwój turystyki } \\
\text { w regionie } \\
\text { LTOs have no visible effect on tourism develop- } \\
\text { ment in the region }\end{array}$ & 2 & 2,27 \\
\hline $\begin{array}{l}\text { Razem } \\
\text { Total }\end{array}$ & 88 & 100 \\
\hline
\end{tabular}


mowania własnej działalności poprzez udział w różnego typu imprezach turystycznych (targi turystyczne, umieszczenie w bazie internetowej) oraz utworzenie sieci informacji turystycznej (32,08\%). Ankietowani deklarowali także możliwość promocji walorów turystycznych, krajoznawczych i historycznych miejsca objętego obszarem działalności LOT (23,12\%). Badani mieli nadzieję, że członkostwo umożliwi im zwiększenie spektrum działania, da więcej możliwości realizacji wspólnych zadań na rzecz rozwoju turystyki (18,34\%). Dużą grupę badanych stanowiły osoby, które postrzegały LOT jako podmiot powszechnie akceptowany, angażujący i godzący różne grupy interesów, a ponadto kumulujący środki zewnętrzne na rozwój sektora turystycznego (14,01\%). Respondenci argumentowali członkostwo zwiększeniem integracji środowiska związanego z branżą turystyczną (6,13\%). Kolejnym argumentem badanych była nadzieja, że zwiększy to liczbę klientów odwiedzających ich miejsca usługowe/turystyczne (4,29\%).

Respondenci określili także korzyści, które wynikają z członkostwa w LOT-ach. Najczęściej są one związane z korzyściami marketingowymi (38,56\%), takimi jak skonsolidowane działania - wspólny udział w targach turystycznych, organizacja wspólnych imprez, zapewnienie tańszej promocji, możliwość udziału w warsztatach i szkoleniach, możliwość bezpłatnej prezentacji ofert i katalogów w Centrach Informacji Turystycznej. Istotna jest także możliwość korzystania z punktów informacji turystycznych rozlokowanych w gminach członkowskich. Badani zauważają ponadto, że LOT-y mają wpływ na działalność na rynku lokalnym - ułatwiają nawiązanie współpracy trójsektorowej (między władzami, organizacjami pozarządowymi i podmiotami gospodarczymi) (24,11\%). Respondenci wskazują na możliwość konsolidacji potencjału ludzi z danego regionu - ich umiejętności, wiedzy i doświadczenia w realizacji wspólnej strategii rozwoju $(17,12 \%)$. Według ankietowanych LOT-y zapewniają ponadto profesjonalizm w działaniach, integrują branżę turystyczną, aktywizują oddolne inicjatywy i pomysły $(8,11 \%)$. Dodatkowo koordynują działania, co pozwala na uniknięcie dublowania (6,14\%). Część badanych nie dostrzega jednak żadnych namacalnych korzyści wypływających z członkostwa-najczęściej związane jest to $\mathrm{z}$ początkową fazą działalności $(5,96 \%)$.

Zadaniami LOT-ów jest m.in. promocja regionu, tworzenie nowych produktów turystycznych czy rozbudowa lub modernizacja infrastruktury turystycznej obszaru. Członków badanych organizacji poproszono o informację, w które działania LOT-ów się angażują. Najwięcej, bo $78 \%$ respondentów, angażuje się w działania promocyjne LOT-ów, ponad połowa (56\%) uczestniczy również w tworzeniu nowych produktów turystycznych, mających na celu przyciągnięcie jak największej liczby turystów i poprawę wizerunku regionu. Prawie 1/3 członków (31\%) angażuje się w ulepszanie infrastruktury turystycznej w regionie. $6 \%$ ankietowanych wskazało również opcję „inne” z możliwością wpisania odpowiedzi nieujętych w kafeterii. Należały do nich: tworzenie informacji turystycznej, wspólne wydawnictwo związane z promocją 
turystyki kulinarnej, konsolidacja działań (klaster). Prawie 5\% respondentów wskazało, że w ogóle nie angażuje się w działania LOT-ów.

Korzyścią wynikającą z członkostwa w LOT-ach jest także możliwość udziału w warsztatach i szkoleniach. Badani najczęściej wskazują, że są one organizowane kilka razy do roku $(48,86 \%)$, sporadycznie $(31,82 \%)$ lub wcale $(11,36 \%)$. Drugim zagadnieniem jest tematyka szkoleń - czy pokrywa się ona z zapotrzebowaniem? W ofercie badanych organizacji dominują szkolenia w zakresie marketingu, organizacji imprez turystycznych i rekreacyjnych oraz przedsiębiorczości, ale żadna z tej tematyki nie występuje nawet u połowy ankietowanych organizacji (kol. $1 \mathrm{w}$ tab. 4). W kolumnie 2 tab. 4 zaprezentowano preferencje członków LOT-ów w zakresie tematyki szkoleń. Badani uważają, że powinny one dotyczyć głównie działań marketingowych (71,59\%), organizacji imprez turystycznych i rekreacyjnych $(67,05 \%)$, komunikacji społecznej $(53,41 \%)$ oraz przedsiębiorczości $(47,73 \%)$. W przypadku trzech obszarów wykazano istotne różnice między oferowanymi i preferowanymi

Tab. 4. Szkolenia organizowane przez LOT-y i preferowane przez ich członków - porównanie Table 4. Topics of training courses organised by LTOs and preferred by their members comparison

\begin{tabular}{|l|c|c|c|c|c|c|}
\hline \multirow{2}{*}{$\begin{array}{c}\text { Tematyka szkoleń } \\
\text { Subjects of courses }\end{array}$} & \multicolumn{2}{|c|}{$\begin{array}{c}\text { Szkolenia organizowane } \\
\text { obecnie } \\
\text { Courses organized } \\
\text { at present }\end{array}$} & $\begin{array}{c}\text { Szkolenia preferowane } \\
\text { przez członków LOT-u } \\
\text { Courses preferred } \\
\text { by members of LT0 }\end{array}$ & \multicolumn{2}{|c|}{$\begin{array}{c}\text { Razem } \\
\text { Total }\end{array}$} \\
\cline { 2 - 8 } & liczba & $\%$ & liczba & $\%$ & liczba & $\%$ \\
\hline $\begin{array}{l}\text { Marketing } \\
\text { Marketing }\end{array}$ & 12 & $40,00^{* *}$ & 63 & $71,59^{* *}$ & 75 & 63,56 \\
\hline $\begin{array}{l}\text { Organizacja imprez turystycznych } \\
\text { i rekreacyjnych } \\
\text { Organisation of tourism-related } \\
\text { and recreational events }\end{array}$ & 11 & $36,67^{* *}$ & 59 & $67,05^{* *}$ & 70 & 59,32 \\
\hline $\begin{array}{l}\text { Komunikacja społeczna } \\
\text { Social communication }\end{array}$ & 6 & $20,00^{* *}$ & 47 & $53,41^{* *}$ & 53 & 44,92 \\
\hline $\begin{array}{l}\text { Przedsiębiorczość } \\
\text { Entrepreneurship }\end{array}$ & 10 & 33,33 & 42 & 47,73 & 52 & 44,07 \\
\hline $\begin{array}{l}\text { Inne } \\
\text { Other }\end{array}$ & 30 & 100,00 & 88 & 100,00 & 118 & 100,00 \\
\hline $\begin{array}{l}\text { Razem } \\
\text { Total }\end{array}$ & 7 & 23,33 & 11 & 12,50 & 18 & 15,25 \\
\hline
\end{tabular}

Test chi-kwadrat, ${ }^{*} \mathrm{p}<0,05,{ }^{* *} \mathrm{p}<0,01,{ }^{* * *} \mathrm{p}<0,001$

Chi-square test. ${ }^{*} \mathrm{p}<0.05{ }^{* *} \mathrm{p}<0.01{ }^{* * *} \mathrm{p}<0.001$ 
szkoleniami (test chi-kwadrat). Znacznie więcej członków wyraża chęć uczestniczenia w kursach dotyczących marketingu $(G=9,382, p=0,0022)$, organizacji imprez turystycznych i rekreacyjnych $(G=8,469, p=0,0037)$ oraz komunikacji społecznej $(G=10,752, p=0,0010)$ niż liczba LOT-ów oferujących takie kursy.

W związku z niepełnym zadowoleniem członków LOT-ów z działalności organizacji, poproszono ich o opinię, w jaki sposób można poprawić jakość i efektywność pracy LOT-ów. Zadaniem ankietowanych było uszeregowanie odpowiedzi według hierarchii ważności (1 pkt - najwyżej w hierarchii, 5 pkt - najniżej). Jako najważniejsze działanie wskazano lepszą integrację członków organizacji, istotne znaczenie miała również poprawa działań promocyjnych oraz tworzenie nowych produktów turystycznych (tab. 5).

Badani ocenili integrację środowiska społeczności lokalnej, jednostek samorządu lokalnego i branży turystycznej na rzecz poprawy atrakcyjności turystycznej na obszarze działania LOT-u jako średnio zadowalającą - polegającą na współpracy w wybranych przypadkach (52,27\%). Część badanych (30,68\%) ocenia ją jako dobrze działającą, odznaczającą się pewną regularnością, 10,23\% badanych deklaruje, że jest to ciągła współpraca - oceniając ją bardzo dobrze. Jedynie $6,83 \%$ badanych nie jest zadowolona z podjętych wspólnych działań, twierdząc, że pomiędzy danymi sektorami nie ma w ogóle współpracy bądź są to sporadyczne działania.

Istotnym czynnikiem wpływającym na funkcjonowanie LOT-ów jest także umiejętność współpracy z pozostałymi jednostkami. Same organizacje, odnosząc się do tej kwestii, miały możliwość udzielenia własnej odpowiedzi, dlaczego współpracują bądź nie z innymi organizacjami. Większość (60\%) respondentów deklaruje współpracę,

Tab. 5. Opinie członków LOT-ów dotyczące niezbędnych działań na rzecz poprawy działalności organizacji

Table 5. The activities required to improve the functioning of LTOs: members' opinions

\begin{tabular}{|l|c|c|}
\hline \multicolumn{1}{|c|}{$\begin{array}{c}\text { Działania wskazane przez członków } \\
\text { Activities specified by members }\end{array}$} & $\begin{array}{c}\text { Średnia } \\
\text { Mean }\end{array}$ & $\begin{array}{c}\text { Odch, std } \\
\text { SD }\end{array}$ \\
\hline $\begin{array}{l}\text { Większa integracja członków organizacji } \\
\text { Better integration of organisation members }\end{array}$ & 2,466 & 1,477 \\
\hline $\begin{array}{l}\text { Lepsza promocja regionu } \\
\text { Better promotion of the region }\end{array}$ & 2,682 & 1,291 \\
\hline $\begin{array}{l}\text { Tworzenie nowych produktów turystycznych w regionie } \\
\text { Creation of new tourism products in the region }\end{array}$ & 2,602 & 1,056 \\
\hline $\begin{array}{l}\text { Lepsze pozyskiwanie funduszy na rozwój turystyki } \\
\text { Better acquisition of funds for tourism development }\end{array}$ & 3,057 & 1,272 \\
\hline $\begin{array}{l}\text { Tworzenie informacji turystycznej } \\
\text { Creation of tourist information }\end{array}$ & 4,193 & 1,240 \\
\hline
\end{tabular}


motywując te działania w różny sposób. Najczęściej zalety płynące ze współpracy dotyczą możliwości zdobycia doświadczenia, wymiany informacji oraz obopólnych korzyści. Część respondentów deklaruje poprawę integracji między członkami, a także udział we wspólnych projektach. Organizacje, które nie nawiązują współpracy (40\%), najczęściej zauważają, że nie ma takiej potrzeby ani wystarczającego zaangażowania z obu stron. Respondenci deklarują także, że nie posiadają wspólnego punktu zaczepienia, np. produktu turystycznego, w który mogliby się zaangażować wspólnie z innymi LOT-ami. Dodatkowo LOT-y wskazują na brak potencjalnych partnerów do współpracy.

\section{Dyskusja}

\section{Rozwój regionów a polityka turystyczna kraju}

Istotnym elementem stymulującym rozwój regionalny jest prawidłowo prowadzona polityka na szczeblu lokalnym, która może być związana z rozwojem branży turystycznej. Jest ona najczęściej wyznaczana przez odpowiednio działające podmioty z sektora usługowego oraz marketingowego, odpowiadającego m.in. za promocję danego regionu czy miejscowości. Kozak (2010) zauważa, że już od dłuższego czasu rozwój gospodarki turystycznej koreluje silnie z szansą na zaktywizowanie niewykorzystanych zasobów, a przez to na rozwój społeczno-ekonomiczny. Potwierdzają to wyniki badań Voltes-Dorty i in. (2014), którzy prowadzili badania porównawcze sytuacji ekonomicznej gmin turystycznych i nieturystycznych w Hiszpanii w latach 2001-2010. Z badań wynika, że gminy rozwijające się turystycznie charakteryzuje większa autonomia finansowa, mniejszy deficyt i zmniejszenie zadłużenia. Biorąc pod uwagę sytuację w Polsce, wiele polskich gmin za główny czynnik rozwoju społeczno-gospodarczego uznało właśnie turystykę, widząc w rozwoju tego sektora szansę na pobudzenie lokalnej przedsiębiorczości, zmniejszenie bezrobocia itp. (Krupa, Soliński 2006).

W Polsce funkcję pobudzającą rozwój turystyki powinny pełnić LOT-y. Nasuwa się jednak pytanie, czy działający w Polsce od 16 lat system spełnia swoje zadanie, czy rzeczywiście LOT-y przyczyniają się do rozwoju turystyki na poziomie lokalnym? Nie wszystkie organizacje funkcjonują od 2000 r.; jak wynika ze struktury biorących udział w badaniu organizacji, tylko połowa z nich powstała w pierwszych pięciu latach funkcjonowania systemu i aż $1 / 5 \mathrm{w}$ ciągu ostatnich trzech lat, ale według badanych członków LOT-ów organizacje te rzeczywiście przyczyniają się do rozwoju turystyki w regionie, a dla $25 \%$ z nich wręcz mają bardzo duże znaczenie. 


\section{Współpraca międzysektorowa a rozwój lokalny}

Często w celu prowadzenia wspólnej polityki turystycznej tworzy się sieci międzysektorowej współpracy, jak np. Lokalne Grupy Działania, w ramach partnerstw terytorialnych, których nadrzędnym zadaniem jest podejmowanie wspólnych działań na rzecz rozwoju społeczno-ekonomicznego w określonych regionach (Furmankiewicz, Stefańska 2010). Wyniki badań własnych także wskazują na istotne zalety, które wypływają ze współpracy pomiędzy sektorem prywatnym a publicznym, pomiędzy różnymi organizacjami. Najczęściej respondenci byli zdania, że współpraca taka umożliwia zdobycie doświadczenia, wymianę informacji, poprawia integrację między członkami, a także umożliwia tworzenie wspólnych projektów.

Według Tosuna (2000) społeczności lokalne, które angażują się w rozwój regionu, charakteryzuje większa świadomość, możliwość wpływania na własne życie i współpracy z innymi podmiotami w kwestiach będących przedmiotem wspólnego zainteresowania, a na przeszkodzie temu zaangażowaniu stoi często centralizacja administracji publicznej zarządzającej turystyką, brak koordynacji działań i brak informacji. W Polsce organizacja zajmująca się promocją turystyki została zdecentralizowana. Współpracę na poziomie lokalnym zapewniają właśnie LOT-y, a ich znaczenie doceniają ankietowani. Jednym z powodów, dla którego członkowie decydowali się na przystąpienie do organizacji, była możliwość zwiększenia spektrum działania przez realizację wspólnych zadań na rzecz rozwoju turystyki oraz zwiększenie integracji środowiska związanego z branżą turystyczną. Ankietowanych zapytano nie tylko o motywy przystąpienia do LOT-u, ale również o korzyści płynące z przystąpienia do organizacji. Pozytywnym zjawiskiem jest to, że częściowo pokrywają się te dwie zmienne. Jako korzyści ankietowani wymieniają m.in. skonsolidowanie działań wspólny udział w targach turystycznych, organizację wspólnych imprez, zapewnienie tańszej promocji, możliwość udziału w warsztatach i szkoleniach. Jako rezultat działalności LOT-ów badani wskazują aktywizację oddolnych inicjatyw i pomysłów. Niestety część respondentów deklaruje brak jakichkolwiek korzyści wynikających z bycia członkiem LOT-u. Jako działania, które usprawniłyby działalność LOT-ów, ankietowani wskazują przede wszystkim lepszą integrację członków organizacji, istotne znaczenie ma również poprawa działań promocyjnych oraz tworzenie nowych produktów turystycznych.

Innym zadaniem LOT-ów jest integracja władz samorządowych, przedsiębiorstw, klubów i stowarzyszeń oraz osób prywatnych zainteresowanych rozwojem turystyki w regionie. Możliwa dzięki tej współpracy konsolidacja działań według respondentów przynosi wiele korzyści (o których wspomniano wyżej). O konieczności współpracy podmiotów w regionie turystycznym pisze Stasiak (2007), podając za przykład dane UNWTO, według których turysta podczas tygodniowego wyjazdu kontaktuje się z 30-50 różnymi podmiotami związanymi z turystyką. Turystyka 
jest dziedziną gospodarki szczególnie predestynowaną do bliskiego współdziałania zaangażowanych w nią jednostek, a LOT-y i ROT-y przyczyniają się do konsolidacji środowiska turystycznego. Kooperacja taka pozwala osiągnąć wiele korzyści - dzięki efektowi synergii partnerzy mogą działać skuteczniej i sprawniej, co jest spowodowane łączeniem komplementarnych zasobów różnych podmiotów (Czernek 2013b). Często kooperacja jest wręcz czynnikiem warunkującym rozwój (Czernek 2013a).

\section{Rozwój lokalny poprzez turystykę - problemy}

Jednym z problemów związanych z rozwojem turystyki w regionie jest zaburzona współpraca podmiotów turystycznych z lokalnymi władzami. Biorąc pod uwagę sytuację LOT-ów w Polsce, jednym z głównych problemów jest właśnie brak świadomości korzyści ze współpracy, mimo że zawarty w obrębie sektora usług turystycznych wymóg wszechstronnej współpracy wynika z istoty oferty komercyjnej (Fedyk, Morawski 2014). Badania własne także wskazują, że integracja środowiska społeczności lokalnej, jednostek samorządu lokalnego i branży turystycznej na rzecz poprawy atrakcyjności turystycznej na obszarze działania LOT-u jest średnio zadowalająca. Charakteryzuje się ona najczęściej współpracą w wybranych przypadkach (52\%), a tylko $10 \%$ członków zadeklarowało, że współpraca ma charakter ciągły.

Wyniki te znajdują potwierdzenie w badaniach innych autorów. Dębski (2014) analizuje funkcjonowanie LOT-u Kraina Wąwozów Lessowych (województwo lubelskie).W tym przypadku aktywność uczestników organizacji uległa zmniejszeniu w momencie rozpoczęcia jej funkcjonowania. Członkowie ograniczają się do płacenia składek, a w zamian oczekują, że będzie ona promować region i stymulować rozwój ruchu turystycznego na jego obszarze. Zawilińska (2010) analizuje sytuację LOT-ów w regionie karpackim Polski, gdzie głównym problemem są niewielkie zasoby finansowe. Dodatkowo chęć podejmowania działań na szerszą skalę jest utrudniona przez brak integracji środowiska lokalnego, szczególnie sektora publicznego i prywatnego.

Dudensing i in. (2011) również wskazują możliwe przyczyny niepowodzeń w rozwoju turystyki w regionie - jednym z nich jest rozmijanie się potrzeb biznesowych i działalności organizacji wspierających turystykę. Rozwiązaniem wskazanym przez autorów jest przede wszystkim udział w szkoleniach, warsztatach i seminariach, z uwzględnieniem dostosowania programu szkoleń do potrzeb. W badaniach omówionych w niniejszym artykule również podjęto problem organizacji szkoleń dla członków LOT-ów. Możliwość udziału w warsztatach i szkoleniach to jedna z korzyści przystąpienia do LOT-u wymienianych przez badanych. Niestety nie w pełni tematyka szkoleń odpowiada potrzebom ich uczestników. Obecnie zbyt mało organizowanych jest szkoleń dotyczących marketingu, organizacji imprez turystycznych i rekreacyjnych oraz komunikacji społecznej. 
W rozwoju turystyki w danym regionie bardzo istotne są wspólne działania marketingowe z innymi regionami (Yang, Fik 2014). W przypadku badanych organizacji tylko $60 \%$ zadeklarowało współpracę z innymi LOT-ami. Wśród głównych motywów niepodejmowania współpracy, ankietowani wskazali m.in. na brak wystarczającego zaangażowania z obu stron, brak wspólnego punktu zaczepienia lub brak potencjalnych partnerów do współpracy. Główne korzyści, jakie czerpią organizacje angażujące się we współpracę ponadregionalną, to przede wszystkim możliwości zdobycia doświadczenia, wymiany informacji i tworzenia wspólnych projektów. Według Fedyka (2013) partnerstwo z innymi LOT-ami może być narzędziem konsolidacji działań w sferze PR, ograniczania kosztów działań promocyjnych czy wzajemnego szkolenia kadr i pozyskiwania dotacji z UE na projekty ponadlokalne. Taka współpraca jest niezbędna przy budowaniu sieciowych produktów turystycznych i usług komplementarnych czy rozszerzaniu katalogu oferty turystycznej. W celu ułatwienia współpracy między LOT-ami w 2009 r. powołano Ogólnopolskie Porozumienie Lokalnych Organizacji Turystycznych. Jest ono formą nieinstytucjonalnej, dobrowolnej współpracy tych organizacji.

Wzmocnieniem wspólnych działań LOT-ów, jak mówi Ryszard Kruk z Federacji Sieć LOT, może okazać się również zjednoczenie LOT-ów: Toruńskiego, Ustki i Ziemi Słupskiej, Krakowskiego, Pojezierza Drawskiego, Wierzycy i Beskidu Niskiego, które przyczyni się do wspólnego wypracowania rozwiązań promujących regiony i wspierających branżę turystyczną. Ponadto wzmocni to obecność poszczególnych LOT-ów na rynku branżowym i pozwoli aktywniej działać na rzecz rozwoju turystyki. Konieczność zjednoczenia się-jest spowodowana nieuporządkowaną działalnością pojedynczych LOT-ów. Brak środków finansowych na prowadzenie jakichkolwiek działań operacyjnych wiązało się z likwidacją wielu organizacji. Okazuje się, że obecnie ze 130 LOT-ów pozostało 80, które mogą wpływać na rozwój turystyki w obszarze swego działania (http://www.wiadomosciturystyczne.pl/aktualnosci/aktualnosci/1339,0,0,0,lot_y_tworza_federacje.html, 29.09.2016).

Ciekawym zagadnieniem jest również współpraca LOT-ów z organizacjami wyższego szczebla - ROT-ami. Według badań Fedyka i Morawskiego (2014) systematycznie rośnie (choć dalej jest niewystarczająca) liczba Lokalnych Organizacji Turystycznych współpracujących z Regionalnymi Organizacji Turystycznych (65,2\%), co świadczy o stopniowym umacnianiu się trójstopniowego systemu turystyki (wg danych za rok 2012 tylko 35\% LOT-ów współpracowało z ROT-ami).

\section{Konkluzje}

Jednym z warunków rozwoju turystyki jest współpraca - zarówno wewnętrzna, pomiędzy różnymi podmiotami działającymi w regionie, jak i zewnętrzna, z innymi 
regionami. Trójstopniowy system promocji kraju ma umożliwić to działanie, niestety mimo upływu 16 lat od czasu uruchomienia systemu wciąż brakuje całościowych analiz dotyczących jego funkcjonowania i kondycji, które pozwoliłyby na przeprowadzenie kontroli i ewentualnych działań naprawczych. Jest to problem zwłaszcza na poziomie lokalnym, gdzie LOT-y powinny stanowić platformę integracji. Niniejsze badania były próbą analizy tej sytuacji, ze względu jednak na niewielkie zaangażowanie organizacji w badanie nie można uznać ich za reprezentatywne. Niski udział w badaniu potwierdza opinię, że część LOT-ów jest zarejestrowana, lecz zupełnie nieaktywna - nie podejmuje znaczących działań, a więc dane statystyczne nie muszą odzwierciedlać rzeczywistej sytuacji w danym regionie.

Informacje uzyskane w trakcie badania pozwoliły na analizę sytuacji w LOT-ach aktywnie działających i ocenę, czy badane organizacje realizują powierzone zadania i jak są oceniane przez członków. Na podstawie wyników można stwierdzić że:

1) Według ankietowanych LOT-y spełniają swoje podstawowe zadanie - przynajmniej częściowo przyczyniają się do rozwoju turystyki w regionie, głównie przez działania promocyjne regionu.

2) Główne korzyści, jakie czerpią członkowie z przynależności do organizacji, to korzyści marketingowe i możliwość konsolidacji działań z innymi członkami.

3) Organizacje powinny zwrócić większą uwagę na integrację różnych grup interesu występujących na danym obszarze. Sposobami na zwiększenie integracji może być otwarcie nowych kanałów komunikacji, organizowanie większej liczby spotkań, w tym również szkoleń i warsztatów.

4) Organizacje powinny bardziej zaangażować się we współpracę międzyregionalną; obecnie tylko $60 \%$ badanych organizacji deklaruje współpracę z innymi LOT-ami.

5) Jednym z zadań, które nie zostało całkowicie realizowane przez LOT-y, jest tworzenie nowych produktów turystycznych.

Przedstawiony materiał może stanowić wstęp do bardziej szczegółowych badań. Według autorów niezmiernie ważnym problemem jest zagadnienie współpracy podmiotów na obszarze działania LOT oraz współpracy z innymi jednostkami. Wskazane byłoby przeprowadzenie dokładnych badań na mniejszym obszarze w obrębie województwa, a więc na obszarze działania ROT-ów. Umożliwiłoby to głębszą analizę współpracy pomiędzy LOT-ami z danego obszaru oraz między LOT-ami i ROT-em z uwzględnieniem specyfiki danego regionu (województwa): walorów turystycznych i rekreacyjnych, istniejącej infrastruktury, sytuacji społeczno-gospodarczej regionu itp.

\section{Literatura}

Adamczyk B., 2005, The National Tourism Organisations of Poland, the Cisech Republic, Slovakia and Hungary - the organisation and activities, Tourism, 53 (3), 247-258. 
Bramwell B., Sharman A., 1999, Collaboration in local tourism policymaking, Annals of Tourism Research, 26 (2), 392-415.

Capone F., Boix R., 2008, Sources of growth and competitiveness of local tourist production systems: An application to Italy (1991-2001), Annals of Regional Science, 42 (1), 209-224.

Cruz da N.F., Marques R.C., 2014, Revisiting the determinants of local government performance, Omega, 44, 91-103.

Cuadrado-Ballesteros B., 2014, The impact of functional decentralization and externalization on local government transparency, Government Information Quarterly, 31, 265-277.

Czernek K., 2013a, Determinants of cooperation in a tourist region, Annals of Tourism Research, 40, 83-104.

Czernek K., 2013b,Organizacje partnerskie na jednym obszarze turystycznym - problemy i wyzwania, Ruch Prawniczy, Ekonomiczny i Socjologiczny, 2, 201-216.

Czernek K., 2015, Rola wspótpracy w stymulowaniu innowacji w gospodarce turystycznej, Studia Ekonomiczne, Uniwersytet Ekonomiczny w Katowicach, 215, 7-18.

Dębski M., 2014, Klaster jako czynnik rozwoju konkurencyjności destynacji turystycznej, Przedsiębiorczość i Zarządzanie, 15 (4/3), 51-66.

Dudensing R.M., Hughes D.W., Shields M., 2011, Perceptions of tourism promotion and business challenges: A survey-based comparison of tourism businesses and promotion organizations, Tourism Management, 32, 1453-1462.

Dynowska J., Rudowicz E., 2007, Oddziaływanie samorzqdu terytorialnego na rozwój lokalny gmin, Acta Scientiarum Polonorum, Oeconomia, 6 (2), 27-35.

Fedyk W., 2013, Kierunki «mian w funkcjonowaniu i efektywności w dziataniu lokalnych organizacji turystycznych na Dolnym Ślqsku, Rozprawy Naukowe Akademii Wychowania Fizycznego we Wrocławiu, 41, 3-20.

Fedyk W., Morawski M., 2014, Regionalne organizacje turystyczne - organizacjami wspótpracy. Prawda czy fatsw?, Folia Turistica, 32, 241-273.

Furmankiewicz M., Stefańska J., 2010, Partnerstwa terytorialne jako sieci organizacyjne. Analiæa powiqzan w træech wybranych ,lokalnych grupach dziatania” w Polsce, Studia Regionalne i Lokalne, 1 (39), 5-25.

Giannone M., 2002, Tourist local systems and territorial development, Journal of Quality Assurance in Hospitality \& Tourism, 3 (1/2), 125-131.

Healey P., 1998, Collaborative planning in a stakeholder society, Town Planning Review, 69 (1), 1.

Howells J., 2005, Innovation and regional economic development: A matter of perspective?, Research Policy, 34, 1220-1234.

http://www.wiadomosciturystyczne.pl/aktualnosci/aktualnosci/1339,0,0,0,lot_y_tworza_federacje.html (29.09.2016).

Jackson J., Murphy P., 2006, Clusters in regional tourism an Australian case, Annals of Tourism Research, 33 (4), 1018-1035.

Kerr B., Barron G., Wood R.C., 2001, Politics, policy and regional tourism administration: A case examination of Scottish area tourist board funding, Tourism Management, 22, 649-657. 
Kozak M.W., 2010, Turystyka: niewykorzystywana sæansa rozwojowa regionów?, Studia Regionalne i Lokalne, 4 (42), 43-59.

Krupa J., Soliński T., 2006, Rola samorzqdu lokalnego w tworzeniu produktu turystycznego regionu, Materiały z III Międzynarodowej Konferencji Naukowo-Technicznej Błękitny San, Dubiecko, http://pogorzedynowskie.pl/data/referaty/IIIBS/ref_25_IIIBS.pdf (29.09.2016)

Malachovský A., Királová A.I., 2015, Invigorating the Destination's Marketing Strategy? (The Case of Slovakia), Procedia - Social and Behavioral Sciences, 175 (2015), 393-400.

McLennan C.J., Ritchie B.W., Ruhanen L.M., Moyle B.D., 2014, An institutional assessment of three local government-level tourism destinations at different stages of the transformation process, Tourism Management, 41, 107-118.

Nermend K., 2009, Vector calculus in regional development analysis: Comparative regional analysis using the example of Poland, Physica-Verlag a Springer Company, Berlin Heidelberg.

Nowacki R., 2009, Potencjat innowacyjny region jako czynnik rowwoju regionalnego, [w:] R. Brol (red.), Gospodarka lokalna i regionalna w teorii i praktyce, Prace Naukowe Uniwersytetu Ekonomicznego we Wrocławiu, 62-71.

Pavlíková B., 2014, Legal acts related to the tourism in Slovakia, Tourism \& Hospitality Papers, 10 (22), 66-79.

Pearce D.G., 1996, Tourist organizations in Sweden, Tourism Management, 17 (6), 413-424.

Russell R., \& Faulkner B., 2004, Entrepreneurship, chaos and the tourism area lifecycle, Annals of Tourism Research, 31 (3), 556-579.

Sharpley R., 2002, Tourism: A Vehicle for Development?, [w:] R. Sharpley, D.J. Telfer (red.), Tourism and development: Concepts and issues, Channel View Publications, Clevedon, 11-35.

Sleuwaegen L., Boiardi P., 2014, Creativity and regional innovation: Evidence from EU regions, Research Policy, 43, 1508-1522.

Stasiak A., 2007, Klaster turystyczny - nowe wyzwanie dla ROT-б́w i LOT-ów?, Rocznik Naukowy Wyższej Szkoły Turystyki i Rekreacji im. M. Orłowicza w Warszawie, 6, 183-196.

Statut Polskiej Organizacji Turystycznej, http://www.pot.gov.pl/o-pot/statut/ (25.11.2013).

Stimson R.J., Stough R.R., Roberts B.H., 2006, Regional economic development: Analysis and planning strategy, Springer Verlag, Berlin-Heideberg.

Szewczuk A., Kogut-Jaworska M., Zioło M., 2011, Rozwój lokalny i regionalny. Teoria i praktyka, Wydawnictwo C.H. Beck, Warszawa.

Tapescu A.I.M., 2015, Romanian versus Bulgarian tourism labour market analysis, Procedia Economics and Finance, 27, 375-384.

Telfer D.J., 2005, Managing tourism for development, [w:] L. Pender, R. Sharpley (red.), The Management of Tourism, SAGE Publications Ltd., London, 188-201.

Tosun C., 2000, Limits to community participation in the tourism development process in developing countries, Tourism Management, 21, 613-633.

Ustawa z dnia 25 czerwca 1999 r. o Polskiej Organizacji Turystycznej (Dz.U. 1999 nr 62 poz. 689 ze zm.; t.j. Dz.U. 2016 poz. 156). 
Voltes-Dorta A., Jiménez J.L., Suárez-Alemán A., 2014, An initial investigation into the impact of tourism on local budgets: A comparative analysis of Spanish municipalities, Tourism Management 45, 124-133.

Yang Y., Fik T., 2014, Spatial effects in regional tourism growth, Annals of Tourism Research, $46,144-162$.

Zawilińska B., 2010, Działalność lokalnych organizacji turystycznych w Karpatach Polskich, Zeszyty Naukowe Uniwersytetu Ekonomicznego w Krakowie, 842, 103-119.

Zmyślony P., 2008, Metoda identyfikacji podmiotów przywódczych rozwoju turystyki w regionach, [w:] K. Dzieńdziura, P. Zmyślny (red.), Spoteczne i ekonomiczne uwarunkowania rozwoju turystyki w regionie, Wydawnictwo Państwowej Wyższej Szkoły Zawodowej w Sulechowie, 69-87.

Agata Stefanowska

Akademia Wychowania Fizycznego Józefa Pitsudskiego w Warszawie

Katedra Zarsqdzania i Ekonomii

ul. Marymoncka 34, 00-968 Warszawa

stefanowska.agata@gmail.com

Maria Lipko-Kowalska

Akademia Wychowania Fizycznego Józefa Pitsudskiego w Warszawie

Katedra Rekreacji

ul. Marymoncka 34, 00-968 Warswawa

m.lipkokowalska@wp.pl 
